\title{
Retinal imaging study diagnoses in COVID-19: a case report
}

\author{
José M. Ortiz-Egea ${ }^{1 *+}$ (D), Jorge Ruiz-Medrano ${ }^{2 \dagger}$ and José M. Ruiz-Moreno ${ }^{1,2,3}$
}

\begin{abstract}
Background: Hyperreflective lesions at the level of ganglion cell (GCL) and inner plexiform retinal layers (IPL) by optical coherence tomography $(\mathrm{OCT})$ and cotton wool spots in the examination of the eye fundus have recently been described as findings in patients with COVID-19 infection.

Case report: We report the case of a 42-year-old healthy Caucasian male anesthetist who had treated COVID-19 patients during the previous 5 weeks and suddenly presented with a temporal relative scotoma in his left eye. Bestcorrected visual acuity was 20/20 for the left eye, and no discromatopsy or afferent pupillary defect was present. Visual field test was performed, with no significant findings associated with the focal loss of sensitivity described by the patient. The anterior segment was unremarkable on slit lamp examination in both eyes. Fundus examination of the left eye showed no significant findings. A placoid, hyperreflective band at the level of the GCL and IPL was visible in OCT which spared the outer retina, at the time of diagnosis and 1 month later. An oropharyngeal swab test was performed for severe acute respiratory syndrome coronavirus 2 (SARS-CoV-2) ribonucleic acid (RNA), immunoglobulin $\mathrm{G}(\mathrm{IgG})$ and immunoglobulin M (IgM) enzyme-linked immunosorbent assay (ELISA) determination. Real-time reversetranscriptase polymerase chain reaction (RT-PCR) was negative. ELISA testing and a third rapid antibody detection test performed 7 days after the onset of symptoms were positive.

Conclusions: Ocular signs and symptoms in COVID-19 cases are rarely reported, but may be underestimated, especially those that affect the retina and occur in asymptomatic or paucisymptomatic cases. We present a case of COVID19 diagnosis based on retinal ophthalmic examination.
\end{abstract}

Keywords: OCT, COVID-19, SARS-CoV-2, Ophthalmology, Retina

\section{Background}

Coronavirus disease 2019 (COVID-19) is caused by severe acute respiratory syndrome coronavirus 2 (SARS$\mathrm{CoV}-2)$. In humans, diseases of the coronavirus family range from the mild common cold to more severe diseases such as Middle East respiratory syndrome (MERS) and SARS [1].

\footnotetext{
*Correspondence: joemortiz@hotmail.com

† Jose M. Ortiz-Egea and Jorge Ruiz-Medrano contributed equally to this work and should be regarded as co-first authors.

${ }^{1}$ Department of Ophthalmology, Castilla La Mancha University, Albacete, Spain

Full list of author information is available at the end of the article
}

COVID-19 can cause pathological ophthalmologic involvement, including conjunctivitis, chemosis, hyperemia, epiphora, secretion [2], photophobia, dry eye [3], neuro-ophthalmic manifestations such as optic neuritis, cranial nerve palsies, nystagmus or visual field defects [4], and descriptions of retinal aggression $[5,6]$.

Optical coherence tomography (OCT) has proved to be a useful tool for the in vivo study of the retina, where hyperreflective structures range from normal retina (nerve, fiber layer, inner and outer plexiform layers), nerve fiber layer myelination or vessels, to lesions such as hard exudates, haemorrhages, fibrosis, or focal inflammation, among others. Some of those imply the appearance original author(s) and the source, provide a link to the Creative Commons licence, and indicate if changes were made. The images or other third party material in this article are included in the article's Creative Commons licence, unless indicated otherwise in a credit line to the material. If material is not included in the article's Creative Commons licence and your intended use is not permitted by statutory regulation or exceeds the permitted use, you will need to obtain permission directly from the copyright holder. To view a copy of this licence, visit http://creativecommons.org/licenses/by/4.0/. The Creative Commons Public Domain Dedication waiver (http://creativeco mmons.org/publicdomain/zero/1.0/) applies to the data made available in this article, unless otherwise stated in a credit line to the data. 
of a shadow below said structures that may lead to interpretation errors [7].

\section{Case presentation}

We present the case of a 42-year-old, healthy Caucasian male anesthetist who had been working with COVID-19 patients during the 5 weeks prior to onset, who presented with a sudden temporal relative scotoma in the left eye. The patient had no previous retinal disease or systemic disease with retinal compromise. Best-corrected visual acuity was 20/20 for the left eye, and no discromatopsy or afferent pupillary defect was present. A visual field test (SITA Fast 30-2) was performed, with no significant findings associated with a focal loss of sensitivity described by the patient. The anterior segment and fundus examination were unremarkable in both eyes.

Swept-source optical coherence tomography (SS-OCT, Topcon Co., Tokyo, Japan) showed a hyperreflective band at the level of ganglion cell and inner plexiform layers, which spared the outer retina (Fig. 1a, b). Multimodal imaging showed neither hypo- nor hyper-autofluorescence in the area. Fluorescein angiography showed no areas of leakage or vascular exudation in early or late phases.

The patient did not report respiratory symptoms, fever or any other clinical symptoms typically described in COVID-19 cases. Thoracic computed tomography imaging did not show lesions compatible with those described in COVID-19 cases with respiratory involvement. Blood tests performed were normal, with no signs of
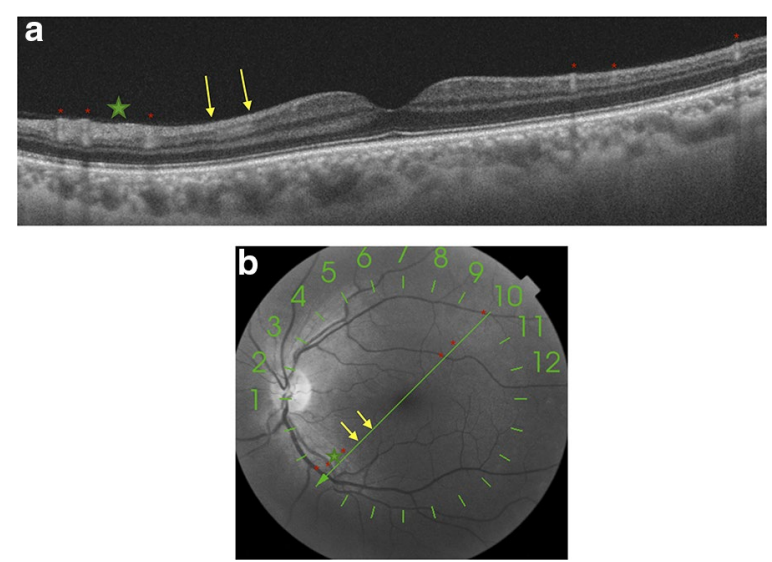

Fig. 1 a and $\mathbf{b}$ Swept-source optical coherence tomography (SS-OCT, Topcon Co., Tokyo, Japan) showed a hyperreflective band (yellow arrows) at the level of the ganglion cell and inner plexiform retinal layers, which spared the outer retina. Green line where the B-scan of the OCT was acquired superposed automatically by the acquisition instrument on an en face infrared fundus image, where there are signs of arterial and venous vessel reflexes (red asterisks) and nerve fiber layer hyperreflectivity (green star) coagulopathy alterations. The patient had normal blood pressure values.

After identifying the aforementioned retinal lesions and considering the patient's high-risk profession with regard to COVID-19 exposure, a pharyngeal swab test for SARS-CoV-2 ribonucleic acid (RNA) and enzymelinked immunosorbent assay (ELISA) determination of immunoglobulin G (IgG) and immunoglobulin $M$ (IgM) were requested. At that time, the patient remembers that he had limited ageusia for several days 3 weeks before the onset of the scotoma. Real-time reverse-transcriptase polymerase chain reaction (RT-PCR) was negative. ELISA testing and a third rapid antibody detection test performed 7 days after the onset of symptoms were positive.

In the subsequent follow-up of the patient 30 days after the start of the scotoma perception, he continued to describe it. Retinal imaging study showed the same hyperreflective lesions observed in SS-OCT, with even greater intensity (Fig. 2a, b), and there were no arteries or veins in the inner layers of the retina on this B-scan that could cause a hyperreflective shadow.

\section{Discussion and conclusions}

Back in 2013, Sarraf et al. were the first to describe the presence of multiple or isolated band-shaped, focal or diffuse hyperreflective lesions visible at the level of the internal nuclear layer in patients who presented with acute onset of a negative scotoma, which they called paracentral acute medial maculopathy (PAMM). PAMM is a

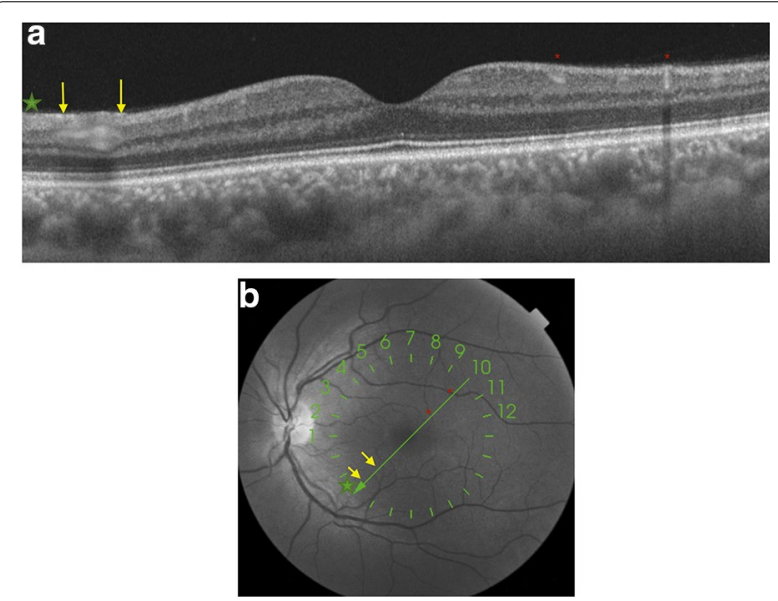

Fig. 2 a and $\mathbf{b}$ One month later, SS-OCT follow-up shows a more prominent hyperreflective band at the level of ganglion cell and inner plexiform retinal layers (yellow arrows). An en face infrared fundus image with a green line where the OCT B-scan was acquired automatically overlaid by the acquisition instrument. On the left, the hyperreflective signal corresponds to the layer of nerve fibers (green star) and reflex vessels (red asterisks) 
spectral-domain OCT (SD-OCT) finding interpreted as a possible more superficial variant of acute macular neuroretinopathy [8].

Its etiology is unknown, although the most commonly supported hypothesis is based on a vascular origin. A localized retinal capillary ischemia at the level of the intermediate plexus has been proposed as the underlying mechanism for the development of these lesions.

As Chen et al. describe, retinal vascular associations leading to retinal vasculopathy and PAMM include eye compression injuries causing global ocular ischemia, sickle cell crisis, Purtscher's retinopathy, inflammatory occlusive retinal vasculitis, pandemic influenza A (H1N1) vaccines reaction, hypertensive retinopathy, migraine disorder and upper respiratory infection [9]. None of these clinical findings was present in our patient.

Early clinical evidence suggests that cases of COVID19 are frequently characterized by hyperinflammation, renin-angiotensin-aldosterone system imbalance, and a particular form of vasculopathy, thrombotic microangiopathy, and intravascular coagulopathy. There are no conclusive studies in paucisymptomatic or subclinical cases [10].

To date, there is very limited evidence of the correlation between COVID-19 and the appearance of retinal lesions, presumably because there is wide clinical variation in the presentation and severity of the disease, which may induce the appearance of different morphological patterns of retinal involvement. Marinho et al. [5], for instance, describe the presence of hyperreflective lesions at the level of ganglion cell and inner plexiform layers more prominently at the papillomacular bundle, but we must be extremely careful with these findings because, as Vavvas et al. [11] point out, OCT hyperreflective bands in the inner retina and/or ganglion cell layer can be confused with normal inner retinal vessels. Landecho et al. [6] recently described cotton wool spots in the retinal fundoscopic examination of the eye and corresponding B-scan OCT showing inflammation of the nerve fiber layer of the retina in 6 of 24 asymptomatic subjects 14 days after discharge from the hospital for treatment for bilateral COVID-19 pneumonia. For this reason, we consider the study with multimodal imaging to be important, agreeing with these authors that we must check at least the near-infrared reflectance record to confirm that the hyperreflective bands do not represent normal vessels (Figs. 1 and 2).

Vascular occlusions described in COVID-19 cases might also be the cause of these retinal findings [10] or may be associated with the neurological manifestations described in animal studies and in COVID-19 neurological events [12-14]. It is possible that these vascular occlusions affect the retinal circulation in its superficial and deep plexuses, generating these areas of hyperreflective signals in the inner layers of the retina. Therefore, and exclusively from an ophthalmological point of view, given the possible implications, COVID-19 infection should be excluded by all available means in cases where these hyperreflective lesions occur at the level of ganglion cell and internal plexiform layer OCT imaging without overlying vessels (infrared fundus imaging helps), to facilitate timely diagnosis and intervention.

This case, and the papers presented by other authors $[5,6,11]$, support the hypothesis that these retinal OCT findings should be considered another sign of COVID-19 disease, hence the importance of retinal imaging study in these patients. Furthermore, to the best of our knowledge, ours is a case of COVID-19 diagnosed through an imaging study of the retina.

\section{Abbreviations}

COVID-19: Coronavirus disease 2019; GCL: Ganglion cell layer; IPL: Inner plexiform retinal layer; OCT: Optical coherence tomography; OS: Left eye; PAMM: Paracentral acute medial maculopathy; RT-PCR: Real-time reverse-transcriptase polymerase chain reaction; SARS-CoV-2: Severe acute respiratory syndrome coronavirus 2; SD-OCT: Spectral-domain optical coherence tomography; SSOCT: Swept-source optical coherence tomography.

\section{Acknowledgements}

We would like to thank Agustín Martínez Alcaraz, PhD, at Hospital Virgen de la Luz (Cuenca; Castilla La-Mancha).

\section{Authors' contributions}

JRM and JMRM analyzed and interpreted the OCT images. JR and JOE acquired the OCT images. JOE was a major contributor in the writing of the manuscript. All authors read and approved the final manuscript.

\section{Funding}

Not applicable.

\section{Availability of data and materials \\ Not applicable.}

Ethics approval and consent to participate

This study was conducted in accordance with the fundamental principles of the Declaration of Helsinki.

\section{Consent for publication}

Written informed consent was obtained from the patient for publication of this case report and any accompanying images. A copy of the written consent form is available for review by the Editor-in-Chief of this journal.

\section{Competing interests}

The authors declare that they have no competing interests.

\section{Author details}

${ }^{1}$ Department of Ophthalmology, Castilla La Mancha University, Albacete, Spain. ${ }^{2}$ Puerta de Hierro-Majadahonda University Hospital, Madrid, Spain. ${ }^{3}$ Red Temática de Investigación Cooperativa en Salud: "Prevención, detección precoz, y tratamiento de la patología ocular prevalente, degenerativa y crónica". RD16/0008/0021, Spanish Ministry of Health, Instituto de Salud Carlos III, Madrid, Spain

Received: 19 October 2020 Accepted: 6 December 2020 Published online: 15 January 2021 


\section{References}

1. Cascella M, Rajnik M, Cuomo A, Dulebohn SC, Di Napoli R. Features, Evaluation and Treatment Coronavirus (COVID-19). In: StatPearls. Treasure Island (FL): StatPearls Publishing; 2020.

2. Wu P, Duan F, Luo C, Liu Q, Liang L, Wu K, et al. Characteristics of ocular findings of patients with coronavirus disease 2019 (COVID-19) in Hubei Province, China. JAMA Ophthalmol. 2020;138(5):575-8.

3. Abdul-Kadir MA, Lim LT. Human coronaviruses: ophthalmic manifestations. BMJ Open Ophthalmol. 2020;5(1):e000630.

4. Gold DM, Galetta SL. Neuro-ophthalmologic complications of coronavirus disease 2019 (COVID-19). Neurosci Lett. 2020. https://doi. org/10.1016/j.neulet.2020.135531.

5. Marinho PM, Marcos AAA, Romano AC, Nascimento H, Belfort R Jr. Retinal findings in patients with COVID-19. Lancet. 2020;395(10237):1610.

6. Landecho MF, Yuste JR, Gándara E, et al. COVID-19 retinal microangiopathy as an in vivo biomarker of systemic vascular disease? J Intern Med. 2020. https://doi.org/10.1111/joim.13156.

7. Cense B, Nassif N, Chen T, et al. Ultrahigh-resolution high-speed retinal imaging using spectral-domain optical coherence tomography. Opt Express. 2004;12:2435-47.

8. Tsui I, Sarraf D. Paracentral acute middle maculopathy and acute macular neuroretinopathy. Ophthalmic Surg Lasers Imaging Retina. 2013;44(6 Suppl):S33-5

9. Chen X, Rahimy E, Sergott RC, Nunes RP, Souza EC, Choudhry N, et al. Spectrum of retinal vascular diseases associated with paracentral acute middle maculopathy. Am J Ophthalmol. 2015;160(1):26-34
10. Henry BM, Vikse J, Benoit S, Favaloro EJ, Lippi G. Hyperinflammation and derangement of renin-angiotensin-aldosterone system in COVID-19: a novel hypothesis for clinically suspected hypercoagulopathy and microvascular immunothrombosis. Clin Chim Acta. 2020;507:167-73.

11. Vavvas DG, Sarraf D, Sadda SR, Eliott D, Ehlers JP, Waheed NK, et al. Concerns about the interpretation of OCT and fundus findings in COVID-19 patients in recent Lancet publication. Eye (Lond). 2020. https://doi. org/10.1038/s41433-020-1084-98.

12. Wang Y, Detrick B, Yu ZX, Zhang J, Chesky L, Hooks JJ. The role of apoptosis within the retina of coronavirus-infected mice. Invest Ophthalmol Vis Sci. 2000;41(10):3011-8.

13. Moriguchi T, Harii N, Goto J, Harada D, Sugawara H, Takamino J, et al. A first case of meningitis/encephalitis associated with SARS-Coronavirus-2. Int J Infect Dis. 2020;94:55-8.

14. Hernández-Fernández F, Valencia HS, Barbella-Aponte RA, Collado-Jiménez R, Ayo-Martín O, Barrena C, et al. Cerebrovascular disease in patients with COVID-19: neuroimaging, histological and clinical description. Brain. 2020. https://doi.org/10.1093/brain/awaa239.

\section{Publisher's Note}

Springer Nature remains neutral with regard to jurisdictional claims in published maps and institutional affiliations.
Ready to submit your research? Choose BMC and benefit from:

- fast, convenient online submission

- thorough peer review by experienced researchers in your field

- rapid publication on acceptance

- support for research data, including large and complex data types

- gold Open Access which fosters wider collaboration and increased citations

- maximum visibility for your research: over $100 \mathrm{M}$ website views per year

At BMC, research is always in progress.

Learn more biomedcentral.com/submissions 